\begin{tabular}{l|l}
$\mathbf{m} \boldsymbol{m}$ & $\begin{array}{l}\text { south } \\
\text { asia }\end{array}$
\end{tabular}

samaj $\begin{aligned} & \text { multidisciplinary } \\ & \text { sama }\end{aligned}$

ui,u academic

III acarnal
South Asia Multidisciplinary Academic Journal

$12 \mid 2015$

On Names in South Asia: Iteration, (Im)propriety and Dissimulation

\title{
To Be Some Other Name: The Naming Games that Hijras Play
}

Vaibhav Saria

\section{CpenEdition}

\section{Journals}

Electronic version

URL: http://journals.openedition.org/samaj/3992

DOI: $10.4000 /$ samaj.3992

ISSN: 1960-6060

Publisher

Association pour la recherche sur l'Asie du Sud (ARAS)

Electronic reference

Vaibhav Saria, «To Be Some Other Name: The Naming Games that Hijras Play », South Asia

Multidisciplinary Academic Journal [Online], 12 | 2015, Online since 12 March 2019, connection on 30

April 2019. URL : http://journals.openedition.org/samaj/3992 ; DOI : 10.4000/samaj.3992

This text was automatically generated on 30 April 2019

\section{(c) $($ () $\odot$}

This work is licensed under a Creative Commons Attribution-NonCommercial-NoDerivatives 4.0

International License. 


\title{
To Be Some Other Name: The Naming Games that Hijras Play
}

\author{
Vaibhav Saria
}

1 Although the hijras appear as a generic category in much official and scholarly discourse that renders them as the 'third gender,' members of these communities themselves pay close attention to the multiple criteria through which one hijra body might be distinguished from another. ${ }^{1}$ This kind of differentiation is reiterated in common talk among the hijras and relates to the moral economy of $i z z a t,{ }^{2}$ or honor. Of the multiple signs through which hijras make their bodies and their sexuality apparent in both the public domain and in interpersonal relations, proper names play a significant role in marking the place of the hijras in the wider sexual economy and also for indexing the changes in the status of a particular person through the life course. From the outside, it might appear that the boundaries of the hijra community are well-defined but from the inside, the community is haunted by questions about who is an asli (real/true) hijra and who might be a nakli or false one (false in the sense of an impostor or a duplicate which carries with it a moral charge of cheating). Distinctions are made through reading very closely the multiple alterations of bodies through surgical and medical interventions, the movement between names, and the volatility of relations in which different subcommunities of hijras are implicated, for differentiating hijra bodies and selves. In this volatile play of who one is, questions about asli and nakli are not simply about social identities but about one's existence as genuine or fake.

2 This paper is based on ethnographic fieldwork I conducted between 2008 and 2010 intermittently and then without any break for a further period between 2011 and 2013 amongst hijra groups in three rural districts of Orissa-Bhadrak, Jajpur, and Kalahandi. Before my fieldwork in Orissa, I belonged to the community of sexual minorities in Calcutta that organized various public events demanding recognition from the state. This is how I first came to register the mutual suspicion among hijras about who is a true hijra. For instance, Shonali, a hijra guru in Bhadrak, did not consider the other hijras of Bhadrak asli (genuine) because they were married to women, ${ }^{3}$ while hijras in Jajpur did not consider any of the hijras of the Bhadrak, including Shonali, asli because, while they 
were organized as a household, they were not members of one of the recognized hijra gharanas (lineages). ${ }^{4}$ Meanwhile, the hijras of Calcutta did not consider any of the hijras from Orissa asli because they earned their living by begging on trains instead of through more respectable activities such as offering their blessings at auspicious occasions such as weddings and childbirth. Also of acute importance in these contestations over asli/nakli hijras was the state of a hijra's genitalia. Certain hijras who had gone through the ritual of castration, called nirvan hijras, did not consider those who had not to be asli hijras, or even hijras at all, dismissing them as kothis (effeminate men) or in moments of high tension and conflict as gandus (sodomites). ${ }^{5}$ Furthermore, hijras who were congenitally third gender often claimed that they alone were asli hijras. Differences between different kinds of thirdness were also marked through participation in regional traditions of theatre and performance: jankhas, jogtas and bhands (actors who impersonate women) were differentiated from asli hijras or absorbed into the category depending upon context (Cohen 1995, Nanda 1999, Pament 2013). Historically, it was this overlap between hijras and participants in various regional traditions of performance that prompted the colonial policing of the hijra in public spaces but also resulted in hijras devising tactics and strategies to evade such policing such as wearing female clothing only in areas beyond British rule or in the privacy of their homes (Hinchy 2014). Furthermore, globalizing discourses on sex and gender lead to the increasing vernacularization of categories such as 'Men who have sex with men' (Boellestorff 2011) and 'transgender,' thus making any neat categorization of the 'third gender' impossible. These complex forces lead us to ask what work the asli-nakli dynamic performs and how proper names are drawn into it?

\section{Ritual and play}

While there is some mention in earlier ethnographies of hijra practices of name changing (from the male name given at birth to a female one) they have not received sustained attention. In addition to describing traditional practices of naming I seek here to extend the discussion by examining how hijras encounter the state and judiciary through the names they bear and how definitions of asliness and nakliness arise and dissolve in these sites.

4 A hijra's decision to join a hijra household as a disciple [cela] to a guru culminates in the ritual of putting rit in that particular household under that guru and it is through this ritual that celas establish their kinship with their gurus. Part of the ritual is to ask the initiate what she would want as her new name. This change in name consolidates the asliness of a hijra and transforms her relation to the local moral world around her as an ascetic because in addition to moving away from her natal village to live with a hijra community elsewhere, usually in a city, the hijra also gives up her surname and consequently her gotra and caste (Nanda 1992: 33-52). While this is the most important instance of the changing of names, it is not the only one in a hijra's life. Hijras also change their names as they switch from one guru to another, or from one hijra household to another due to an altercation with the guru. For example, Kalavati, a senior cela (disciple) of a hijra guru in Jajpur, was thrown out of the hijra household there in the following manner. Her fellow cela, a hijra named Sandhya, had fallen in love with a man who was already in a relationship with another cela of the same household, Chandni. Sandhya seduced the young man and embarked on an affair, which led to him eventually leaving Chandni for her. A fight quickly ensued between the two hijras over the young man after 
Sandhya's affair and betrayal of her fellow cela was discovered. Since Sandhya and Chandni lived in the same house with Guruma (the guru) and nine of her other celas and nati-celas, ${ }^{6}$ including Kalavati, the household was quickly divided with each hijra aligning herself with either Sandhya or Chandni. Guruma, in order to broker some peace, had penalized Sandhya for seducing her fellow cela's partner but had not commented on whether she would allow Sandhya to continue her relationship. Later in the week, Kalavati not only encouraged Sandhya to get married to her lover but also took them to the marriage registrar where she signed the marriage certificate as a witness. When this came to light, another fight ensued and Guruma, now even more enraged, saw fit to penalize Kalavati as well for instigating the affair. Kalavati promptly ran away to Bhadrak (my field site) in the middle of the night and asked for shelter and protection from Shonali, the hijra guru in Bhadrak. Shonali took on Kalavati as a cela and after undergoing the ritual of rit; she was given a new name-Kaajal. Another instance of changing names following a dispute took place during my fieldwork when Lakshmi, a young hijra from Bhadrak, left her guru Priya, with whom she had lived in the neighboring district of Jalasore, and returned to her natal home. I greeted her and asked her how she was doing, addressing her by the name Lakshmi, as she had been known. She did not respond and after a few minutes said, 'Lakshmi died, she was Priya's cela. I am Madhabi.'

I read this changing of names as ritualized games that hijras play. By 'ritualized' I mean to emphasize that names were not changed on a whim but carried the structural features of transitions that mark a change in the hijra's status and were accompanied by rituals that facilitated such change. By characterizing these as 'games' I wish to indicate the register of the subjunctive that often meets its limits in the actual in the sense that the previous name continues to cling to the hijra, defining obligations that she was trying to escape. I noted in many cases that in spite of the name changing rituals they underwent, hijras could not simply shed the pasts in which their earlier names were implicated. ${ }^{7}$ While the renaming might have allowed a hijra to temporarily walk away from the fights, conversations, and the form of non-biological kinship that hijras practice, it did not generate a completely new person. In Madhabi's case, she could not become Priya's cela again even with a new name, despite her ardent wish to do so. While Lakshmi signaled the break from Priya by taking a new name, neither Priya nor the community could erase the memory of the wounding fight that had led to the severing of relations between her guru and her previous self. In later conversations with me, Priya would often use the name Lakshmi and not Madhabi as she cursed her, using abusive language about her as if the new name and the person bearing that name did not exist for her. Similarly, Kalavati's new name did not mean that she could escape the fine and punishment that was meted out to her by her former guru. She was caught by the hijras of Jajpur and brought back to undergo the humiliating ritual of expulsion that would strip her of her membership from that household. This rite involved returning the tweezers, called darsan, that hijra celas are given by their guru, paying an exorbitant fine, and finally undergoing the humiliating rite called thuk ke chatna in which the cela is required to spit on the hijra guru's feet and forced to lick them clean. It was only after begging forgiveness and undergoing this ritual that she was allowed to return to Bhadrak to her new guru as Kaajal.

6 The analogy between ritual and play has been used by scholars to show the 'as if character of ritual enactments. Seligman et al. (2008: 20) propose that we understand 'ritual as a subjunctive-the creation of an order as if it were truly the case.' They further argue that though 'the subjunctive world created by ritual is always doomed ultimately to 
fail' because it 'can never fully replace the broken world of experience,' the practice of rituals not only gives us temporary respite from this brokenness but also equips us to deal with them (Seligman et al. 2008: 31). Building on this insight I want to argue that the changing of names also has an as-if character in that it reveals a particular modality-that of playfulness as the mode in which one engages one's past. The new names of hijras enacted an 'as if self-one that could be completely severed from its past, but like the subjunctive in rituals, these names, too, failed to accomplish a complete break from the past in the face of the real world. Kalavati and Priya could not escape humiliation and punishment at the hands of their gurus. However, the ultimate failure of ritual gamesthe hardness of the real as it hits against the wishful construction of new identities-came to the fore most forcefully in accusative discourses of asli-nakli when hijras had to confront the institutions of the state. As we shall see below, the male names of hijras persisted and resurfaced in such moments leaving them vulnerable to accusations of being nakli while also reminding them of their erstwhile male names and what they constituted and entailed.

\section{The names I was called}

7 In recent years there has been a concerted effort on the part of both national and state level government to include hijras in its various schemes addressing poverty, inequality and corruption. This is evident in the attempt to include hijras in the 2011 census of India, and in schemes such as the Unique Identification Number, through provision of a box labeled 'other' alongside 'male' and 'female.' This box labeled 'other' for the hijra to mark is duplicated across various sites of the state from identification cards to-most recently-passports. These efforts to render the hijra commensurable with the state culminated in the 2012 landmark case of National Legal Services Authority vs the Union of India, which recognized third gender citizens and granted them equal fundamental rights (writ petition (civil) no. 400 of 2012). Yet these efforts towards commensurability paradoxically create conditions ripe for the enactment of violence on and violation of the hijra body.

8 The state's efforts to provide its services to the hijra conjoin with the logic of rendering them as a population to be documented and enumerated through technologies of governmentality. But these efforts to bring hijras under the governmental gaze come up against the fact that hijras change their names multiple times. Since various officials, both from state institutions such as the DAPCU (District AIDS Prevention Control Unit) and NGOs who run programs related to prevention and treatment of HIV and AIDS, assume that the female names taken by hijras are not stable they assign the male names that the hijras were given at birth on official documents as proof of identity. This created a new set of problems that I witnessed during my fieldwork. For instance, since hijras were recruited as local experts for HIV prevention, they were required to travel to various places and needed government issued documents to prove identity. A prominent NGO in Bhadrak arranged for identification papers for the hijras, but the documents carried the male names given to them at birth. In one instance, the male name created an embarrassing situation for Lovely, for even if she travelled in male clothes she had already modified her body through the use of hormones to the extent that she would not, at first glance, be identified as a man. She was forced to confess to the official at the airport that she was a hijra and had to endure the humiliating staring, whispering and 
giggling that ensued amongst various airport officials. Another transgendered person told me,

Since all my documents are in my male name, I stood in the security line for male people but then the guard screamed, 'Madam this is for men, your line is over there.' It is so embarrassing; people stare at you, wondering what is happening. They begin whispering, everybody's attention is on you. Now I always go to the female line and there when I am in the booth, I tell the lady. 'I am like this, you tell me what to do, should I go to that line or stay here.' Usually, the lady officer just says, 'No problem, arre you look just like a woman.'

9 Hijras in Bhadrak and Jajpur usually travel on trains and in groups. Given that begging in trains is common among hijras in Orissa, they were well known to railway officials and conductors. This familiarity did not always prevent violence, thus, hijras were always prepared for some altercation. This preparedness was usually signaled by the way hijras announced themselves in the trains; by their loud claps that served as identification enough. In other spaces that required state documentation, such as airports, the male names on official documents spelt trouble since the names (male) and the looks (female) did not match. The disjuncture evoked the suspicion of something clandestine: were their names and documents asli or nakli-real or forged? Let me provide one more example of how the asli-nakli dynamic became linked with the male names of hijras. When the officials collecting data for the 2011 census reached the districts of Jajpur, they insisted on recording the male names of the hijras who lived in one of the hijra households. A hijra who worked as a school teacher in her village before joining the Jajpur household told me, 'I read in the newspaper that there was an option for 'other' in the census, so I asked the man why he was marking us as 'male' instead of using the option of recording us as hijras.' The man told her, 'oh, hijras are men.' In the ensuing argument the official demanded to see whether they were castrated as proof of their being hijras. Since a lot of the young hijras had not undergone the ritual of castration, they were made to feel ashamed and ended up being counted as males. Recently hijras have begun to respond to these pressures for a stable name by using the word Kinnar as their last name, which, as I mentioned above, they have to give up when taking a hijra name. However, since local officials hold on to certain ideas of asli and nakli as this example demonstrates, hijras mostly end up using the male name for official purposes. ${ }^{8}$

10 The resurgence of the hijras' male names not only rehearses the limits under which the state's imagination of the hijra and her body function, but also indexes a suspicion of criminality. I proceed now to (re)assemble a number of recent court cases in which hijras were implicated in crimes of murder and bodily harm against either other hijras or against clients and lovers.

\section{The hijra and the hands of justice}

11 My interest in the presence of the hijra in the legal archive began when Shamsheri, a hijra in Bhadrak, showed me certain legal documents relating to her divorce from her wife. Shamsheri had been convinced by her elder brother to take on his mistress as her wife. The marriage was a ruse to provide cover for the mistress's pregnancy resulting from her clandestine relations with Shamsheri's already married brother. Shamsheri was willing to do this favor for her brother who wished to continue the relationship with his mistress. This amicable arrangement between the brothers and the mistress quickly soured when the elder brother wanted to end the relationship. The document Shamsheri 
showed me was an order sheet issued by the Judicial Magistrate of First Class, which is the second lowest criminal court in India. The order sheet had the pronouncement that Shamsheri had to pay 1500 rupees as maintenance to her wife. The issue of maintenance had been brought under the criminal court because Shamsheri's wife, wishing to avenge herself on her former lover, had charged Shamsheri with domestic violence, a criminal offense under section 498 of the Indian Penal Code. In addition, Shamsheri was accused of making demands for dowry, which once again was a criminal offense. Nowhere in the documents was Shamsheri identified as a hijra. Her male name was used for the entire proceeding and gave the impression that it was a case of a man who allegedly tortured his wife for dowry, beat her and threatened to abandon her to a life of destitution if she left him. While this might be an instance of the law refusing to recognize Shamsheri as a hijra because she was married to a woman, it raises questions pertinent to the cases I cite below which indicate different patterns in the use of male or hijra names depending on whether the hijra stands before the court as an accused or as a victim or witness of crime.

12 Pratiksha Baxi, in her recent work on the juridical construction of rape, argues that 'juridical categories, incommensurable with the survivor's experience, deployed during the rape trial, convert rape into sex and sex into rape' (Baxi 2014: 346). The court, Baxi shows, relies on a certain set of fictions of the body and persons to judge whether the victim was raped or not. Any deviation from a certain recognized narrative of violence offered in the process of adjudication creates doubt on the claim of rape resulting in high rates of acquittal. In other words, if the story of the rape does not accord with the preconceptions of what a rape victim's behavior must be like, then the courts are likely to conclude that the sex was consensual and the woman faked the story of rape to cover up consensual sex. I want to extend this argument in order to ask how the court adjudicates the asliness and nakliness of hijras as a way of establishing criminality and its implications.

13 A survey of the reported appellate judgments that deal with hijras reveals an intriguing pattern in the circulation of their male and female names. Since only the judgments of high courts and the Supreme Court are reported, and even then only upon the judge's recommendation, it is not surprising that most of the cases in which hijras appear as the accused deal with a serious criminal offence, such as murder. Apart from reported judgments, the High Court also hears appeals to judgments that were delivered by lower courts, so we also have access to part of the legal proceedings in the appellate courts that become archived in the public record. A brief survey of these documents reveals how the law imagines the relation between naming and the body. Otherwise stated, the question is, how do courts name identity and locate criminality in the name?

14 Take the case of Mantori @ Noor Mohd. vs State (MANU/DE/1525/2009) in which the hijras named Mantori and Bijli were held guilty of the murder of another hijra named Rekha. While Mantori and Bijli have their male names, Noor Mohammod and Laccho, respectively, recorded, Rekha's male name is not given. The facts of the case were that in 1989, Rekha, who was a disciple of Bijli, was murdered by Mantori and her guru. The body was discovered in a jungle near the Idgah Mehrauli in Delhi by a patrolling chowkidar. The document is striking because of the pattern in which it names people who were involved in the crime. The male names of Mantori and Bijli are affixed like aliases in the document, but several other hijras, like the victim, Rekha, or the witnesses Meena and Anita, do not have their male names recorded. Whilst recording the multiple names of a person might be part and parcel of legal proceedings that must identify a criminal, the male names of hijras are not aliases-they are actively suppressed by hijras themselves 
because it is precisely leaving that name behind that is part of their transformation into a hijra.

15 We see how legal documents record the male names of hijras in ways, which suggest they are equivalent to each other, like aliases, in several other cases. Thus, in the case of Shabbir @ Neha vs State Govt. of NCT of Delhi (MANU/DE/3909/2012), Neha and a fellow hijra, identified in the document as Om Prakash also known as Helen, are accused of killing their customer Atiq in Woodland Park. The difference between a hijra and a man is erased by linking the excised male name as alias with the female name to generate a suspicion of nakliness that is confirmed by their criminality. This erasure is achieved by mentioning the male name of the hijra as if it had a bearing on the case. In the case "Vijay urf Rupa Kinnar versus the state of Allahabad' (Criminal Misc. Bail Application No. 2156 of 2010 (2010) H.C. Allahabad), Rupa and her friend Manbhari (identified in the document with an alias-Akbar) were accused of killing an unnamed hijra. A witness, Jodh Singh, saw them carry the dead body at midnight. We can tell that the court recognized the persons concerned as hijras because the Additional Government Advocate had 'argued that the applicants had motive for committing the crime, as there was some monetary dispute between the parties, who were eunuchs.' The linking of the male names with female names, even when recognizing the persons concerned in the case as hijras, implies a relationship between criminality and maleness, which would raise doubts of asliness.

16 We can see this implication in the case Kashmira @ Salim vs. State (Delhi High Court, Criminal Appeal No. 725/2005) in which Kashmira is accused and later convicted of murdering a certain Daya Ram. I find it interesting that the court found it necessary to record that 'Kashmira used to dress up as female and claimed that she was the wife of Daya Ram.' Given that hijras are expected to dress in female attire and have husbands, such specific mention of Kashmira's propensity to do just that, makes her hijraness nakli and reduces the facts of her existence to a spurious claim or disguise. While none of the documents show a conscious intention on the part of the law to render hijra criminals nakli, the circulation of her male name as an alias signals towards her nakliness because they refigure the hijra as a male who is in the guise of a female rather than a hijra with a female name.

17 It is not that hijras do not or cannot have male names-demanding that the hijra have a female name would replicate calls for asliness and denunciations of nakliness. Since hijra identities and bodies change slowly over time, pill by pill, and through decisions both big and small that range from the sartorial to the familial, it is quite possible that the hijra has different names and different genders in different documents. She may have a male name and gender recorded on her birth certificate but a female name and gender on her bank account documents, while being marked 'other' on her passport and Aadhaar card. ${ }^{10}$ The fact that the male name of the hijra is recorded only to impute a cause to her criminality renders the male name as evidential rather than incidental to a hijra's life.

The attribution of a male identity to the criminal seems to accord with the judicial presumption that criminality is more 'natural to the male' than the female as argued by Veena Das (1996) in her study of rape trials in India. Das remarks that 'in the process of judicial verification, courts construct the category of young males, who are acting out their impulses and 'irrepressible sexual urges' when they rape women' (2420). If the law mitigates the violence committed by young men by naturalizing their sexuality then could we also argue that the law in the cases cited above adheres to a gendered etiology of violence? By citing the male names of hijras it adheres to a conceptualization of 
maleness that is defined by its propensity towards violence. By discounting intentionality, I am relying on the notion of the 'juridical unconscious' as put forward by Felman (2002: 57), who writes that 'Legal memory is constituted, in effect, not just by the 'chain of law' and by the conscious repetition of precedents but also by a forgotten chain of cultural wounds and by compulsive or unconscious legal repetitions of traumatic, wounding legal cases.' I want to invoke this unawareness that the law has regarding itself in order to understand its underlying commitment to sex and biology that renders them true and everything else derivative and virtual. I shall return to this point in the next section.

The maleness of the hijra that is unconsciously implied through the use of her male name as a criminal alias is further thrown into relief when we see that hijras are allowed to keep their hijra names only in instances when they are dead or when they are not accused of crimes. So for example, in the case of State vs Shree aka Mani Gopal (MANU/ DE/1918/2009), Neelam, a single-named hijra who was a witness to the murder of another single-named hijra called Zareena, is shot dead by the multiply-named criminal Shree Gopal aka Mani. Thus, it cannot be that it is usual procedure to collect the male names of hijras to ensure their asliness. It could be argued that given that the male names of hijras are actively suppressed it would be impossible to discover and record them in the case of their death if their family members could not be tracked. We do not see police recording the male names of hijras who are alive and are witnesses to crime either-but surely there is a stake in verifying the identity of victims and witnesses? Even where the male name of the hijra can be recorded because of access to family members it is not if her criminality is not at stake. For instance, in the case Babu Lal vs the State (Rajasthan High Court, Criminal Appeal no. 870/2005), a woman named Ratni Devi is killed by one of her sons, either Ramesh or Babu Lal aka Pappu. The hijra offspring called Susheela is a witness in the case and while her family members might easily have provided her male name, it is not recorded.

\section{The hijra's penis}

Let me turn now to how the law qualifies the nakliness of the hijra criminal by consolidating her male name through sex and biology. Given that the popular definition and understanding of hijras reduces them to their castrated status, it is possible that police officers when reporting the hijra murderers had insisted on checking whether the hijra criminal was castrated or not and that the male name of the hijra was attached to the criminal upon finding them uncastrated. This form of harassment is routine even when there is no crime committed. For example, during my fieldwork in the rural districts of Orissa, I found that the police would regularly patrol the spots where hijras solicit customers and force them to remove their clothes. Upon finding them (still) uncastrated, they would be taken to the police station and threatened with being put in jail. The hijras would plead for mercy and pay a bribe to be set free. ${ }^{11}$ I note that none of the court documents that I have cited mention whether the hijra was castrated or not. Thus, the effect of maleness was produced here primarily through language or, more specifically, by the interpellation of the hijra by her male name. The implication of biology through language is clearly seen in the case Kumkum vs State (Delhi High Court, Criminal Revision Petition 414/2010). The judgment upheld the sentence of imprisonment for one year, meted out because Kumkum was caught begging and booked under the 
Bombay Prevention of Begging Act, 1959. Throughout the petition Kumkum was called a 'male hizara (sic),' which I take to mean that she was not castrated.

Let me further illustrate how the biology and sex of hijras is produced in the context of law and criminality. Pravallika, a hijra, was murdered on January 17, 2015, in Hyderabad. While reports of this murder were carried by many English language dailies, the details of the case that emerged later were only reported via online NGO networks and statements released by the Telangana Hijra Transgender Samiti (THTS). The statement went as follows:

On the evening of Tuesday, 20th January 2015 i.e. yesterday, our friend, a Hijra sex worker was taken away for interrogation to the KPHB police station. She is a colleague and friend of the late Pravallika and us. On the pretext of interrogation, the police blamed her for conspiring to murder Pravallika and resorted to subhuman methods. The police caught her while she was returning home from her hot spot and confiscated her mobile first to ensure that she couldn't contact anyone for help. The police had themselves urged her in our presence at the Gandhi hospital mortuary to continue going to the hot spot. We were a minimum of 20 who witnessed this request from the police. They said that they suspected that Pravallika may have been murdered by her clients and hence wanted to use our Hijra friend as a bait and a decoy. Despite this, she was treated like a criminal, DENUDED by policemen with the alleged reason of 'checking whether or not she was really a transwoman.' She had to remain nude for 4-5 hours as they manhandled and tortured her, questioning her transidentity all through, as she was uncastrated. She told them that transidentity cannot and should not be restricted to a person body or be reduced to one's anatomy as enshrined in the NALSA judgement but the police demonstrated total disregard for the NALSA vs. UOI judgement of the Supreme court.

Naked as she was in the biting cold of a wintry night, she pleaded for her clothes but they couldn't care. Finally, with no other option left, she was constrained to reveal her HIV+ve status and explain that she is highly vulnerable to infections and that she can't afford to be nude for so long in such cold weather. Sadly, that too fell on deaf ears. This only resulted in them keeping a safe distance from her having masked their noses and mouths but they didn't return her clothes to her. Our sister transgender is very ill now and struggling the consequences of this torture.

Pravallika's mobile is now on surveillance after her death. Preliminary investigations revealed that some police personnel were in touch with her before her murder. They claimed to be 'just her friends.' It is nothing new that the policemen who harass and torture Hijra people often seek free sexual favors from them and call themselves just their friends when found in such compromising situations. With this coming to light and the unusual urgency shown by the police to paint this case as an 'intra-hijra feud leading to Pravallika's murder,' the very role of the police appears suspect and perhaps complicit in this crime.

As much as we would like to and wish to, we ARE NOT ABLE TO TRUST the police anymore and demand that the following at the earliest:

1. Judicial enquiry for a free, fair and transparent investigation of Pravallika's murder

2. Release of the post mortem report and FIR

3. Speedy implementation of the NALSA judgement

The statement made by the THTS shows us how the biology of the hijra can be conjured up to fit the asli-nakli dynamic and consequently be used to locate violence. Pravallika's asliness goes unquestioned when it can easily be argued that perhaps her nakliness was the reason for her murder, especially if it was an 'intra-hijra feud'-violence between hijra groups sometimes pivot around accusations of nakliness. The tortured hijra's penis not only becomes evidence for her nakliness but is also taken as evidence for a propensity 
towards violence. The penis is made to appear when criminality needs to be proven, though it disappears in the context of intimacy and sexual transactions. For instance, in the context of sexual interest, men would often refer to the hijra's anatomy explicitly as female; they would talk about her breasts, her vagina and her capacity to give birth. The protocols of flirting would never allow for enquiring after the presence or absence of the hijra's penis. ${ }^{12}$

The appearance of the hijra penis in contexts of murder and disappearance in contexts of sexual transactions between 'friends' implies that there is a critical distance between the penis and the phallus and that a change in context allows the former to become the latter. It is helpful here to return to Butler's (2002) emphasis on the distance as well as the relationship between the phallus and the penis. As is well known, Butler argues that 'the law is not simply a cultural imposition on an otherwise natural heterogeneity; the law requires conformity to its own notion of 'nature' and gains its legitimacy through the binary and asymmetrical naturalization of bodies in which the Phallus, though clearly not identical with the penis, nevertheless deploys the penis as its naturalized instrument and sign' (2002: 135). The hijra's penis only appeared as a phallus when legal contexts demanded a signification of violence, which in the cases described above was murder, and was achieved through male names. Such signification marks the presupposition of maleness and its inherent propensity towards violence. The penis is evacuated of the symbolic phallus when intimacy and/or sexual transactions are the orders of the moment. Let me explain this further.

Leo Bersani in his article on Almodovar's film All About my Mother calls attention to the presence of the penis on the bodies of several transsexuals in order to ask whether these penises constitute the paternal phallus or conversely should be seen as contesting the symbolic. He studies the scene in which several women, with and without penises, are talking about the penis and 'make it an object of fun, not exactly something to be made fun of, but rather something to have fun with' (2010: 77). Bersani offers the provocation that, 'Unlike the absent father and the fantasmatic phallus, the Almodovarian penis is present even where, in principle, it should not be: on the bodies of such (at least selfproclaimed) women as Agrado and Lola. The penis's many reoccurrences help to dephallicize it' (Bersani 2010:77-8). If the penis can be dephallicized even in its occurrence, that is to say if it can exist without symbolizing power and authority, then the question that can be posed from the gendered reporting of violence committed by and on hijra bodies is this: what does law achieve by reading the physiological penis as the symbolic phallus or by equating the penis with maleness and in turn with criminality? It seems to me that the hijra penis, when accused of murder and in turn of nakliness, enables the courts to arrive at an association between maleness and murder. This association brings forth a confrontation in which psychoanalysis throws into sharp relief the problem of law's epistemological foundation. While the Oedipal tragedy makes 'visible the unconscious foundation of the symbolic life,' law grapples precisely with the problem of 'representing the question of tragedy, the ancient discourse of destiny summoning Oedipus' (Legendre 1998:178-86). Let me first anchor the pertinence of the Oedipal drama in order to understand the asli-nakli dynamic that I have shown pervades not just hijra aspirations for authenticity but other social processes as well, such as the legal understanding of violence. In the South Asian case, Robert Goldman contests the absence of the Oedipal tragedy in Sanskrit epics and writes, 
For it is my strong feeling that in exclusively relying upon the manifest or stated relationships in many important episodes, scholars have tended to overlook the very marked tendency in some types of Oedipal story towards the substitution of various male figures, notably the guru or aged brahman sage, and to a much lesser extent the elder brother, for the father and female figures such as the guru's wife, the sister-in-law, and often a cow, for the mother (1978: 327).

He further reminds us of the legitimacy of substitution by remarking that,

It was in fact the recognition of such substitutions that led Freud to his most fundamental discoveries about the operation of the unconsciousness and therefore about the science of psychoanalysis itself. For it was his realization that the figures of friends, colleagues, etc. in his dreams and those of his patients were in fact representations of parental and other important figures that enabled him to produce The Interpretation of Dreams (Goldman 1978: 367 n. 16).

It is thus only by substituting actual fathers for father figures, more specifically the brother, that we can see the epics Ramayana and Mahabharata as tales of Oedipal violence and tragedy. Let us return to Legendre's provocation that psychoanalysis renders impossible a legal rendition of tragedy. We can see how the hijra criminal results in an analogous dilemma. If the hijra is expected to be asocial, an ascetic who has walked away from the duties of the householder, forsaken the oedipal tragedy and its promising futurity, then how is her criminality to be understood in terms other than nakliness given that her asliness is defined by her incorruptibility? ${ }^{13}$ Legendre writes that 'It is in light of a textual arrangement of spacing necessary for the life of a representation, for the reproduction of the animal that speaks, that the function of reference may be apprehended as a logical function of society. Such a function has as its task to put into play, in the unconscious representations of the subject, the power to institute separation by words. We are concerned with the essence of the symbolic function' (181-2). The essence of the phallus with which the court cases and police reports imbue and refer to the hijra penis not only consolidates a certain idea of maleness but also configures the hijra within a normative oedipal development and thus render her nakli.

\section{The incorruptibility of the asli hijra}

26 The figure of the hijra politician serves as the perfect foil for the hijra criminal because, if the latter is made nakli because of her criminality, the former is mimetically constituted as incorruptible and hence asli. Hijra politicians never stand on their male names. They are not only made famous through their female names but their hijraness and consequently their incorruptibility depends on those names and on the breaking from one set of obligations signified by the male name and the taking on of another through female ones such as Shabnam Mausi, Asha Devi, Manisha Aai, and most recently Madhu Kinnar, the elected mayor of Raigarh. Apart from such well-documented and spectacular instances of hijras attaining political offices, many more local instances were visible in rural Orissa. During the course of my fieldwork I was taken to meet a hijra in her mid fifties who had won elections at the block level. While in our brief conversation she emphasized that she was elected because people knew she was honest and hard-working, the government officer who had taken me to meet her rehearsed the logic that it was because she could not have a family that she was incorruptible. Similarly, Jaina and Azgari, who were the oldest and senior most hijras in Bhadrak were often called upon to sit on local neighborhood committees that oversee the management of funds collected for local celebrations, precisely because of their purported incorruptibility. The different 
connotations of the male and the female name for defining hijra identity in the eyes of the state point towards the wider gender dynamics that inform judicial and administrative reasoning and thus the limits of the subjunctive that ritual tries to enact through the name changing practices of the hijras.

\section{Conclusion}

Based on extended fieldwork among the hijras and an assembling of legal documents in which hijras were implicated as criminals, I have argued that the multiple names that hijras take during their life course index changes in bodies, kinship status, and position within their social milieu. These name-changing practices also encode the erosion of relationships and the hopes for new and different futures. But as subjects of the state, hijras' multiple names create problem for both it and them. The state, as we have seen, seeks to render hijras commensurable with its technologies of government. The male names of hijras in the legal documents that I examined not only reveal the dynamic of asli -nakli but also the imagination of violence as quintessentially male in the juridical unconscious. I read the juridical interpretation of hijras as criminals to argue for the relevance of psychoanalytical theories in thinking about law and representation. Paradoxically, the social field is drawn between the criminality of the nakli hijra and the incorruptibility of the asli hijra. If names are actualizations of different phenomenological, juridical and temporal properties of the person that move between the public and the private, the generic and the singular, then the volatility of hijra names provides us with a unique perspective on the movement between the subjunctive and the actual, the real and its doubles, through which relationships are sustained and destroyed.

\section{BIBLIOGRAPHY}

National Legal Services Authority versus Union of India and others. Writ petition (civil) no. 400 of 2012. (2012) Supreme Court of India.

Shabbir @ Neha versus State Govt. of NCT of Delhi. Crl. Appeal No. 580/2009 (22nd August, 2012) H.C.Delhi.

Vijay Urf Rupa Kinnar and Another vs State Of U. P., Criminal Misc. Bail Application No. 2156 of 2010 (2010) H.C. Allahabad.

Babu Lal @ Pappu versus State Govt. of NCT of Delhi, CRL. Appeal 627/2008 (26 March, 2010) H.C. Delhi.

Kumkum (male Hizara) versus State Govt. of NCT of Delhi, Crl. Revision Petition No.414/2010. (September 6th 2010) H.C. Delhi.

Kashmira @ Salim versus State Govt. of NCT of Delhi. Appeal No.725/2005 (14th October, 2009) H.C. Delhi. 
Shree Gopal @ Mani Gopal versus State Govt. of NCT of Delhi, CRL. Appeal 528/2009 (31 August, 2009) H.C. Delhi.

Mantori @ Noor Mohd. and Laccho @ Bijli and Babu Khan versus State Govt. of NCT of Delhi. CRL. Appeal 11/2001 (6 August 2009) H.C. Delhi.

Bersani, Leo (2010) 'Aggression, Gay Shame, and Almodovar's Art' in Is the Rectum a Grave? And O ther Essays, Chicago: University of Chicago Press.

Boellstorff, Tom (2011) 'But Do not Identify as Gay: A Proleptic Genealogy of the MSM Category', Cultural Anthropology, 26(2), pp. 287-312.

Baxi, Pratiksha (2014) Public Secrets of Law: Rape Trials in India, New Delhi: Oxford University Press. Butler, Judith (2002 [1990]) Gender Trouble: Feminism and the Subversion of Identity, New York and London: Routledge.

Cohen, Lawrence (1995) 'The Pleasures of Castration: The Postoperative Status of Hijras, Jankhas and Academics', in Paul R. Abramson \& Steven D. Pinkerton (eds.), Sexual Nature/Sexual Culture, Chicago: University of Chicago Press, pp. 276-304.

Cohen, Lawrence (2005) 'The Kothis Wars: AIDS Cosmopolitanism and the Morality of Classification', in Vincanne Adams \& Stacey Leigh Pigg (eds.), Sex in Development: Science, Sexuality, and Morality in Global Perspective, Durham: Duke University Press, pp. 269-303.

Cohen, Lawrence (2004) 'Operability: Surgery at the Margin of the State', in Veena Das \& Deborah Poole (eds.), Anthropology in the Margins of the State, New Delhi: Oxford University Press, pp. 16590.

Copeman, Jacob; Ikegame, Aya (eds.) (2012) The Guru in South Asia: New Interdisciplinary Perspectives , New York: Routledge.

Cover, Robert M. (1986) 'Violence and the Word', Yale Law Journal, 95(8), pp. 1601-29.

Das, Veena (1996) 'Sexual Violence, Discursive Formations and the State', Economic and Political Weekly, 31(35), pp. 2411-23.

Felman, Shoshana, (2002) The Juridical Unconscious: Trials and Traumas in the Twentieth Century, Cambridge: Harvard University Press.

Goldman, Robert. P. (1978) 'Fathers, Sons and Gurus: Oedipal Conflict in the Sanskrit Epics', Journal of Indian philosophy, 6(4), pp. 325-92.

Hinchy, Jessica (2014) 'Obscenity, Moral Contagion and Masculinity: Hijras in Public Space in Colonial North India', Asian Studies Review, 38(2), pp. 274-94.

Hussain, Delwar (2013) Boundaries Undermined: The Ruins of Progress on the Bangladesh-India Border, London: Hurst.

Legendre, Pierre (1998) 'The Other Dimension of Law', in David Gray Carlson \& Peter Goodrich (eds.), Law and the Postmodern Mind, Ann Arbor: University of Michigan Press.

Nanda, Serena (1999) Neither Man nor Woman: The Hijras of India, Belmont, CA: Wadsworth Publishing Company.

Pamment, Claire (2013) 'The Bhand Mode of Performace in Pakistani Performance' Ph.D. thesis, Royal Central School of Speech and Drama, University of London.

Puett, Michael J. (2014) 'Ritual Disjunctions: Ghosts, Philosophy, and Anthropology' in Veena Das, Michael D. Jackson, Arthur Kleinman \& Bhrigupati Singh (eds.), The Ground Between: Anthropologists Engage Philosophy. Durham: Duke University Press, pp. 218-33. 
Reddy, Gayatri (2006) 'Honorable Mentions: Izzat in the Hijra Moral Economy', in Mariza Correa \& Erica Renata de Souza (eds.), Family Life: A Comparative Perspective on Crimes of Honour, Sao Paulo: University of Campinas (UNICAMP), Centre for Gender Studies.

Reddy, Gayatri (2005) With Respect to Sex: Negotiating Hijra Identity in South India, Chicago: University of Chicago Press.

Reddy, Gayatri (2003) “Men' Who Would Be Kings: Celibacy, Emasculation, and the Re-Production of Hijras in Contemporary Indian Politics', Social Research 70(1), pp. 163-200.

Saria, Vaibhav (forthcoming) 'The Pregnant Hijra: Laughter, Dead Babies, and Invaluable Love' in Clara Han and Veena Das (eds.), Living and Dying in the Contemporary World: A Compendium, Berkeley: University of California Press.

Saria, Vaibhav (2014) 'The Perfumed Semen: The Labour of Loving in Rural Orissa, India', Ph.D. (unpublished dissertation), Johns Hopkins University, Baltimore.

Seligman, Adam P.; Weller, Robert P.; Puett, Michael J.; Bennet, Simon (2008) Ritual and its Consequences: An Essay on the Limits of Sincerity, Oxford: Oxford University Press.

\section{NOTES}

1. For a recent discussion of this shifting criteria making amongst hijras, please see Delwar Hussain (2013). Though Hussain was talking about hijras who eke out a living through sex work on the India-Bangladesh border, it shows the persistence and widespread nature of the concern with identifying real hijras.

2. Gayatri Reddy, defines izzat as follows: 'A Farsi word originally, the term izzat refers most closely to the constellation of meanings glossed in English as honor or respect' and shows how it is used by hijras to evaluate their status, identity, practice and behavior $(2006,487)$.

3. I explore the spatial organization of hijra communities in Bhadrak and the multiple relations they maintained with their formally wedded wives, their husbands and male lovers many of who were also their clients, in my PhD dissertation (see Saria 2014).

4. The guru-cela relationship that is characteristic of hijra kinship seeks to replace biological kinship and thus requires hijras to renounce their familial duties; how successful this endeavor is an important topic to study but is outside the purview of this article. The relationship is an important marker of hijras' asceticism and thus also a qualification of being ritual-specialists. Both Gayatri Reddy (2005) and Serena Nanda (1999) have studied this extensively. Not every gurucela relationship seeks to replace biological kinship; some actually aim to supplement it. Please see Copeman \& Ikegame (2012) for other models of the guru-cela relationship.

5. Please see Cohen (2005) for a description and analysis of such a contest over accusations of being nakli.

6. Nati-celas are disciples of the disciple of the guru. They are analogous to grandchildren or natis.

7. On the subjunctive character of ritual see Puett (2014).

8. The word Kinnar itself refers to a hijra but it is an attempt to accrue more respect than the word hijra which is a word thrown around pejoratively amongst non-hijras.

9. I gratefully acknowledge the help of Pratiksha Baxi, Sruti Chaganti, and Pooja Satyogi who have helped me track and understand these legal documents.

10. Gayatri Reddy has documented that in the hijra household in Hyderabad where she conducted her fieldwork hijras were often recorded in the archive of the hijra household with Muslim male names irrespective of their religion even when they were given hindu female names upon initiation. Though these names were not used or circulated for addressing the hijra till they 
reached the level of the seniority of a nayak in the hierarchy or hijra social organization, they served the purpose of consolidating the inheritance of and identification with Islam of the hijras rather than maleness. This was reflected in the fact that the hijras who were members of a hijra gharana in Orissa would also have Muslim names recorded but female ones and once again they were recorded but not circulated. The fact that the legal documents show no concern for such a carefully administered circulation of the male name, which once again is not the male name that hijras were given at birth, let alone an alias, reveals the jurispathic tendencies of law. Robert Cover (1986) has argued 'that judges of the state are jurispathic-that they kill the diverse legal traditions that compete with the state' (1610). The fact that in the legal documents I have cited there is no mention of hijra rituals and Hindu male names are recorded as well as Muslim ones, without the clarification of where and how those names were acquired reveal a commitment to a certain idea of biology at the expense of the fact that hijras themselves might have a different relationship to violence through which they would gauge justice and culpability.

11. The familiarity between the police officers and the hijras resulted not only from the regular harassment for bribes but also because Bhadrak, Jajpur and Bhawanipatna (the district headquarter of Kalahandi) were small towns. The regularity of such harassment meant only that this violence was gratuitous given that the police already knew who was castrated and who wasn't.

12. I would like to thank one of my reviewers who pointed out that nakli could also mean 'copy' or 'imitation' from its usage in Urdu and not just false which is the way it is used in Hindi. This allows me to note that often in the marketplaces of Bhadrak (which has the highest proportion of the Muslim population in Orissa) where the hijras would flirt and engage in very sexual conversations with men, the word nakli would be used not so as to imply that the hijra was actually a male person but that she was a 'copy' or an 'imitation' of a woman because she could not give birth to children. Thus, in the contexts of intimacy and flirting the word nakli would be used by men to provoke hijras into inviting them to try and get them pregnant. For example, the protocols of flirting would be as follows: A young man might say to a hijra, 'oh what can you give me? You are not a real woman, can you get pregnant?' The hijra might respond and say, 'Why don't you try and get me pregnant?' or 'You can't get me pregnant because your own weapon is not working and you are blaming me.' In the context of violence though, nakli would imply falseness indicative of corruption. Please see Saria (forthcoming).

13. Hijras claim to be incorruptible because of their asceticism. The discourse they deploy to ratify their incorruptibility understands the existence of family as pressing a moral force of kinship that explains if not excuses the corruption of people, specifically of politicians. Hijras are not the only people who equate the lack of family and biological kinship with the lack of corruption; several politicians also claim such a vantage point to make a case to garner votes during elections. I shall be discussing the figure of the hijra politician in the next section. Please see Gayatri Reddy (2003) and Lawrence Cohen (2004) for a discussion of the figure of the hijra politician.

\section{ABSTRACTS}

This article begins by studying the ritualized changing of names that hijras undertake and proposes that we understand them as a subjunctive, which is to say that these rituals create an order in which names and the selves they entail can be shed for new ones. I then show that the 
failure of this subjunctive mode of fashioning one's past and future is met in its confrontation with the law, which names the hijra in a discernible pattern in order to locate criminality and identity with her male name. I argue that this implication of maleness reveals a commitment not only to biology and sex but also an Oedipal understanding of violence. This understanding links naming with the dynamic of asli (real) and nakli (false) and draws a social field between the two through the figures of the hijra politician and the hijra criminal.

INDEX

Keywords: hijra, ritual, law, psychoanalysis, criminality

\section{AUTHOR}

\section{VAIBHAV SARIA}

Institute of Socio-Economic Research on Development and Democracy (ISERDD), New Delhi 